\title{
Colette Camelin-Catherine Mayaux, Saint-John Perse
}

\section{Emanuele Kanceff}

\section{(2) OpenEdition}

\section{Journals}

\section{Edizione digitale}

URL: https://journals.openedition.org/studifrancesi/41117

DOI: 10.4000/studifrancesi.41117

ISSN: 2421-5856

\section{Editore}

Rosenberg \& Sellier

\section{Edizione cartacea}

Data di pubblicazione: 1 juillet 2004

Paginazione: 218-219

ISSN: 0039-2944

\section{Notizia bibliografica digitale}

Emanuele Kanceff, «Colette Camelin-Catherine Mayaux, Saint-John Perse», Studi Francesi [Online], 142 (XLVIII | I) | 2004, online dal 30 novembre 2015, consultato il 09 septembre 2021. URL: http:// journals.openedition.org/studifrancesi/41117 ; DOI: https://doi.org/10.4000/studifrancesi.41117

\section{Questo documento è stato generato automaticamente il 9 septembre 2021.}

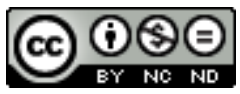

Studi Francesi è distribuita con Licenza Creative Commons Attribuzione - Non commerciale - Non opere derivate 4.0 Internazionale. 


\title{
Colette Camelin-Catherine Mayaux, Saint-John Perse
}

\author{
Emanuele Kanceff
}

\section{NOTIZIA}

Colette Camelin-Catherine mayaux, Saint-John Perse, Paris, Memini, 2003, pp. 344

(«Bibliographie des Écrivains Français», 26).

1 Nella pregevole e meritoria collana B.E.F., «Bibliographie des Écrivains Français», delle edizioni Memini, bibliografia tematica delle letterature francofone europee, esce con il n. 26 questo folto volume dedicato a Saint-John Perse. Esso si presenta secondo la formula editoriale prevista fin dagli anni Novanta, quando la collezione fu fondata, arricchita da alcune sezioni peculiari: Territoires, che s'ispira al percorso geografico del poeta ed è suddivisa in "Antille et créolité», «Chine et Extrème Orient», "Amérique»; Bibliotheque génétique, Traduction, dedicata alla «biblioteca» dello scrittore, alla genesi dei suoi poemi, ai commenti relativi alle traduzioni delle sue opere; StylistiqueRhétorique, che si articola in sezioni sul lesico, la stilistica, la retorica, l'informatica; Ontologie, Philosophie, Spiritualité, che raggruppa le interpretazioni filosofiche dell'opera; Esthétique, Histoire littéraire, Réception, in cui sono incluse pittura e musica; Études des correspondances e Catalogues d'expositions.

2 In tale ricchezza appare limitata e quasi forzata la sezione Desiderata, il cui compito è d'indicare le nuove direttrici d'indagine che emergono dal bilancio degli studi presentati.

3 A rimedio dell'obbiettiva difficoltà di consultazione da parte del lettore, in pericolo di disperdersi tra tante sezioni, vengono i numerosi indici finali, che tuttavia non riescono a tranquillizzare totalmente il ricercatore sul fatto che nulla sia sfuggito in questo rimescolamento di carte bibliografiche. 